TAPROBANICA, ISSN 1800-427X. May, 2021. Vol. 10, No. 01: pp. 54-57.

(C) Research Center for Climate Change and Department of Biology, Faculty of Mathematics \& Natural Sciences, University of Indonesia, Depok 16424, INDONESIA.

http://www.taprobanica.org

https://doi.org/10.47605/tapro.v10i1.248

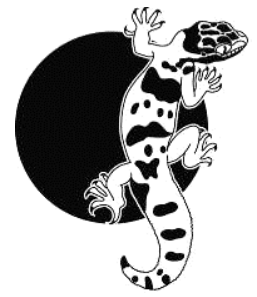

\section{Ichthyofauna of Maben Wathurawa Swamp Forest, southwestern Sri Lanka}

In Sri Lanka, the highest number of endemic and threatened freshwater fish species is found in the south-west and most records are from outside the protected area network. They may therefore be severely impacted by anthropogenic activities (Pethiyagoda 1994, Goonatilake et al. 2020). Forested streams support higher fish biomass than non-forested streams (Lo et al. 2020), and almost all the endemics are strongly associated with shaded habitats (Pethiyagoda 1991). The Maben Wathurawa Swamp Forest (hereafter MWSF; Fig. 1), has been proposed as a forest reserve for several decades (Survey General Ceylon 1972) but there is no information available on the ichthyofaunal assemblages in that forest.

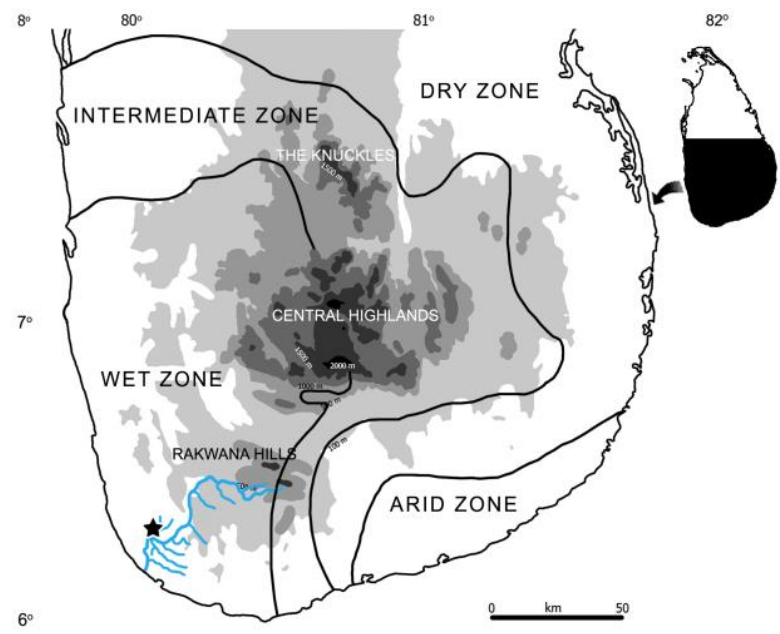

Figure 1. Location of the Maben Wathurawa Swamp Forest (star) and the Gin River Basin (in blue) in south-west Sri Lanka. (C) Map: A.A.T. Amarasinghe

MWSF is flooded periodically by water from the Maben-Ela tributary connects to the Gin River at Agaliya, creating several ephemeral streams and pools in the low-lying parts of the forest. These pools are considered to be the most important habitats and breeding grounds for diverse endemic and indigenous fish species.
Thus, the present study aimed to document the ichthyofaunal assemblages and ascertaining the status of fish species in MWSF $\left(6^{\circ} 117.00^{\prime \prime}-\right.$ $6^{\circ} 14^{\prime} 19.61 " \mathrm{~N}, 80^{\circ} 10^{\prime} 5.85^{\prime \prime}-80^{\circ} 14^{\prime} 10.53 " \mathrm{E}$; alt. 4-150 $\mathrm{m}$ a.s.1.), which is located in the Welivitiya-Divitura Divisional Secretariat Division in Galle District of southern Sri Lanka. The MWSF is relatively dry from January to April (dry season) and receives heavy rain during the rest of the year (wet season), mainly from the southwest monsoon from May to September. We carried out this study during both dry and wet seasons from January to December 2018. During the wet season, water bodies throughout MWSF are connected but during the dry season, water bodies are not connected and act as refuges for fish.

Sampling localities were chosen to cover all fish habitats. The physicochemical parameters, temperature, $\mathrm{pH}$, dissolved oxygen (DO) and total dissolved solids (TDS) were measured in each sampled water body by using a hand held environmental multi-probe (Hanna, USA: model HI 98194) submerged $15 \mathrm{~cm}$ below the surface until value stabilized. Fish samples were collected by seining with a small-meshed net (300 $\mathrm{cm}$ in length and $150 \mathrm{~cm}$ in width, stretched mesh size $8 \mathrm{~mm}$ ). The physicochemical data are summarized in Table 1. All parameters fluctuated within a narrow range between wet and dry seasons. Fish were identified to species level with the aid of field guides (e.g. Deraniyagala 1952, Pethiyagoda 1991, Goonatilake 2007, De Silva et al. 2015), taxonomic references (e.g. Silva et al. 2008, Pethiyagoda et al. 2012, Sudasinghe \& Meegaskumbura 2016, Sudasinghe et al. 2016) and recent taxonomic reviews (e.g. Abesinghe $e t$ al. 2020, Sudasinghe et al. 2020a-f). A checklist of the species was produced along with the National IUCN status (NS) of species in Sri Lanka and Global IUCN status (GS) of those same species were listed based on Goonatilake et al. 2020 (Appendix).

We recorded a total of 34 fish species belonged to 28 genera from 17 families. 21 
species are indigenous (61.8\%), a further nine are endemic $(26.5 \%)$ and four exotic $(11.8 \%)$. Two indigenous species; Puntius vittatus and Rasbora dandia, and one endemic species; Pethia cumingii were the most prevalent at $49.89 \pm 4.24 \%, 11.33 \pm 2.82 \%$ and $24.05 \pm 6.53 \%$, respectively. Of the exotic species, Osphronemus goramy was the most prevalent at $0.44 \pm 0.17 \%$. Over $50 \%$ of fish belonged to four families. Cyprinidae was the most diverse family represented by 13 species, followed by Channidae and Ospronemidae each with three species. The family Cichlidae was represented by two species. The other families (see Appendix) were represented by a single species each. Based on IUCN Red List status 19 species are of Least Concern (LC), four are Endangered $(\mathrm{EN})$, four are Vulnerable (VU) and three are Near Threatened (NT), see Appendix.

Table 1. Physicochemical parameters of waters in MWSF, Sri Lanka during 2018; dry season = January-April, wet season $=$ May-December.

\begin{tabular}{lccc}
\hline parameter & $\begin{array}{c}\text { dry } \\
\text { season } \\
( \pm \mathrm{sd})\end{array}$ & $\begin{array}{c}\text { wet } \\
\text { season } \\
( \pm \mathrm{sd})\end{array}$ & $\begin{array}{c}\text { average } \\
( \pm \mathrm{sd})\end{array}$ \\
\hline \multirow{2}{*}{ temperature $\left({ }^{\circ} \mathrm{C}\right)$} & 26.65 & 26.45 & 26.51 \\
& \pm 1.2 & \pm 0.2 & \pm 0.6 \\
$\mathrm{pH}$ & 6.30 & 6.56 & 6.50 \\
& \pm 1.1 & \pm 0.5 & \pm 0.7 \\
$\mathrm{DO}(\mathrm{ppm})$ & 5.76 & 5.61 & 5.65 \\
& \pm 0.9 & \pm 0.4 & \pm 0.6 \\
TDS $(\mathrm{ppt})$ & 0.02 & 0.01 & 0.02 \\
& \pm 0.0 & \pm 0.0 & \pm 0.0 \\
\hline
\end{tabular}

The family Cyprinidae is the most speciose group of freshwater fishes in the world (Muchlisin et al. 2015) and was also the dominant family recorded from the MWSF ecosystem. It also accounts for $30.9 \%$ of freshwater fish species recorded from Sri Lanka (Goonatilake et al. 2020). Flooding from monsoonal rains in the wet season creates a network of freshwater swamps that is considered by some to be one of the most spectacular in the world (Siriwardana \& Sangasumana 2018).

Freshwater fish species, inhabiting undisturbed natural habitats have well defined niche segregation and ecological adaptations evolved over centuries. But tropical freshwater forest biodiversity is rapidly declining due to anthropogenic pressure (Lo et al. 2020), and exotic species have become established mainly in highly disturbed areas where no native fish now occur (Senanayake \& Moyle 1982).
Invasive exotic species usually predate on local fish, compete with local species for habitat and food (Alcaraz \& Garcia-Berthou 2007), interfere with mate selection (Seehausen et al. 1997) and transmit disease to local species (Almodovar et al. 2006). There is a low prevalence of exotic invasive species (morphotypes of Pterygoplichthys pardalis and P. disjunctivus) in MWSF, indicating that they have not become well established in this swamp forest (Abesinghe et al. 2020). MWSF has been proposed as a reserved forest based mainly on the terrestrial biodiversity. The present findings on fish fauna add weight to that proposal, warrant encouraging policymakers to fulfill the long-term plan of declaring MWSF as a reserved forest.

\section{Acknowledgements}

We would like to acknowledge the Faculty of Fisheries and Marine Sciences \& Technology, University of Ruhuna for funding (grant No: RU/FMST/RP/2017/04).

\section{Literature cited}

Abesinghe, A., H. Sudasinghe, A. Amarasinghe, F. Fareed et al. (2020). The identity of the exotic Pterygoplichthys sailfin catfishes in Sri Lanka (Teleostei: Loricariidae). Zootaxa, 4852 (1): 145-150.

Alcaraz, C. and E. Garcia-Berthou (2007). Food of an endangered cyprinodont (Aphanius iberus): ontogenetic diet shift and prey electivity. Environmental Biology of Fishes, 78 (3): 193207.

Almodovar, A., G.G. Nicola, B. Elvira, and J.L. Garcia-Marin (2006). Introgression variability among Iberian brown trout evolutionary significant units: the influence of local management and environmental features. Freshwater Biology, 51 (6): 1175-1187.

Deraniyagala, P.E.P. (1952). A Coloured Atlas of some Vertebrates from Ceylon, Vol. 1, Fishes. National Museums of Ceylon, Colombo: 149pp.

De Silva, M.A., N. Hapuarachchi, and T. Jayaratne (2015). Sri Lankan freshwater fishes. Wildlife Conservation Society, Galle: 391pp.

Goonatilake, S. de A. (2007). Freshwater Fishes of Sri Lanka [in Sinhala]. Ministry of Environment and Natural Resources, Sri Lanka: 147pp.

Goonatilake, S. de A., M. Fernando, O.W. Kotagama, N, Perera et al. (2020). The National Red List of Sri Lanka: Assessment of the Threat Status of the Freshwater Fishes of Sri Lanka. In: Miththapala, S. (ed.). The 
National Red List of Sri Lanka. IUCN Sri Lanka and the Biodiversity Secretariat, Ministry of Environment \& Wildlife Resources: $106 \mathrm{pp}$.

Lo, M., J. Reed, L. Castello, E.A. Steel et al. (2020). The influence of forests on freshwater fish in the tropics: A systematic review. BioScience, 70 (5): 404-414.

Muchlisin, Z.A., Q. Akyun, S. Rizka, N. Fadli et al. (2015). Ichthyofauna of Tripa Peat Swamp Forest, Aceh Province, Indonesia. Check List, 11 (2): 1560.

Pethiyagoda, R. (1991). Fresh water fishes of Sri Lanka. The Wildlife Heritage Trust of Sri Lanka, Colombo: 362pp.

Pethiyagoda, R. (1994). Threats to the indigenous freshwater fishes of Sri Lanka and remarks on their conservation. Hydrobiologia, 285: 189201.

Pethiyagoda, R. M. Meegaskumbura, and K. Maduwage (2012). A synopsis of the South Asian fishes referred to Puntius (Pisces: Cyprinidae). Ichthyological Exploration of Freshwaters, 23 (1): 69-95.

Seehausen, O., F. Witte, E.F. Katunzi, J. Smits, and N. Bouton (1997). Pattern of the remnant cichlid fauna in southern Lake Victoria. Conservation Biology, 11 (4): 890-904.

Senanayake, F.R. and P.B. Moyle (1982). Conservation of freshwater fishes of Sri Lanka. Biological Conservation, 22: 181-195.

Silva, A., K. Maduwage, and R. Pethiyagoda (2008). Puntius kamalika, a new species of barb from Sri Lanka (Teleostei: Cyprinidae). Zootaxa, 1824 (1): 55-64.

Siriwardana, S.H.S.M. and ven. P. Sangasumana (2018). The Impact of anthropogenic intervention on the Walauwewaththa Wathurana Fresh Water Swamp Forest in Sri Lanka. International Journal of Multidisciplinary Studies, 5 (2): 130-138.

Sudasinghe, H. and M. Meegaskumbura (2016). Ompok argestes, a new species of silurid catfish endemic to Sri Lanka (Teleostei: Siluridae). Zootaxa, 4158 (2): 261-271.

Sudasinghe, H., R. Pethiyagoda, K. Maduwage, and M. Meegaskumbura (2016). Mystus nanus, a new striped catfish from Sri Lanka (Teleostei: Bagridae). Ichthyological Exploration of Freshwaters, 27 (2): 163-172.

Sudasinghe, H., E.A.S. Adamson, R.H.T. Ranasinghe, M. Meegaskumbura et al. (2020a). Unexpected species diversity within Sri Lanka's snakeheads of the Channa marulius group (Teleostei: Channidae), Zootaxa, 4747 (1): 113-132.
Sudasinghe, H., R. Pethiyagoda, and M. Meegaskumbura (2020b). A molecular phylogeny of the genus Laubuka (Teleostei: Cyprinidae) in Sri Lanka reveals multiple origins and a cryptic species. Systematics \& Biodiversity, 18 (6): 592-613.

Sudasinghe, H., R. Pethiyagoda, and M. Meegaskumbura (2020c). Evolution of Sri Lanka's Giant Danios (Teleostei: Cyprinidae: Devario): teasing apart species in a recent diversification. Molecular Phylogenetics \& Evolution, 149: 106853.

Sudasinghe, H., R. Pethiyagoda, M. Meegaskumbura, K. Maduwage, and R. Britz, (2020d). Channa kelaartii, a valid species of dwarf snakehead from Sri Lanka and southern peninsular India (Teleostei: Channidae). Vertebrate Zoology, 70: 157-170.

Sudasinghe, H., R. Pethiyagoda, R. Raghavan, N. Dahanukar et al. (2020e). Diversity, phylogeny and biogeography of Systomus (Teleostei, Cyprinidae) in Sri Lanka. Zoologica Scripta, 49: 710-731.

Sudasinghe, H., R. Pethiyagoda, R.H.T. Ranasinghe, R. Raghavan et al. (2020f). A molecular phylogeny of the freshwater-fish genus Rasbora (Teleostei: Cyprinidae) in Sri Lanka reveals a remarkable diversificationand a cryptic species. Journal of Zoological Systematics \& Evolutionary Research, 58: 1076-1110.

Survey General Ceylon (1972). Transverse Mercator Projection, Ambalangoda. R.A. Gooonewardena, Acting Survey General of Ceylon, Survey Department of Ceylon.

Submitted: 25 Dec. 2020, Accepted: 10 May 2021 Section Editor: Upali S. Amarasinghe

K.H.M.A. Deepananda ${ }^{1,3}$, K. Wewalwala ${ }^{2}$, P.K.W.I.N. Rathnayake ${ }^{1}$, H.M.V. Udayantha ${ }^{1}$, G.A.T.K. Yomal ${ }^{1}$, R.B.D.D. Senarathne ${ }^{1}$, A.U. Kuragodage ${ }^{1} \&$ S.U. Thuduwage ${ }^{2}$

${ }^{1}$ Department of Fisheries \& Aquaculture, Faculty of Fisheries, Marine Sciences \& Technology, University of Ruhuna, Matara, Sri Lanka

${ }^{2}$ Biodiversity Education and Exploration Society, Wackwella Road, Galle, Sri Lanka

${ }^{3}$ E-mail: ashoka@fish.ruh.ac.lk 
Appendix. Species checklist in MWSF with the IUCN conservation status (based on Goonatilake 2020), and the prevalence of species; E, endemic; I, indigenous. * exotic, NS, national status; GS, global status; LC, Least Concern; EN, Endangered; NT, Near Threaten; VU, Vulnerable; — not applicable

\begin{tabular}{|c|c|c|c|c|}
\hline \multirow{2}{*}{ Family and species } & \multirow{2}{*}{ Common name } & \multicolumn{2}{|c|}{ IUCN status } & \multirow{2}{*}{ Prevalence \pm sd } \\
\hline & & NS & GS & \\
\hline \multicolumn{5}{|l|}{ Anabantidae } \\
\hline $1 \quad$ Anabas testudineus ${ }^{\mathbf{I}}$ & climbing perch & $\mathrm{LC}$ & $\mathrm{LC}$ & $0.27 \pm 0.1$ \\
\hline \multicolumn{5}{|l|}{ Anguillidae } \\
\hline 2 Anguilla bicolor ${ }^{\mathbf{I}}$ & level-finned eel & NT & NT & $0.17 \pm 0.1$ \\
\hline \multicolumn{5}{|l|}{ Aplocheilidae } \\
\hline $3 \quad$ Aplocheilus parvus ${ }^{\mathbf{I}}$ & dwarf panchax & $\mathrm{LC}$ & $\mathrm{LC}$ & $0.13 \pm 0.0$ \\
\hline \multicolumn{5}{|l|}{ Bagridae } \\
\hline $4 \quad$ Mystus nanus $\mathbf{I}$ & Stripped dwarf catfish & $\mathrm{LC}$ & $\mathrm{LC}$ & $0.25 \pm 0.2$ \\
\hline \multicolumn{5}{|l|}{ Belonidae } \\
\hline$X_{\text {Xenentodon cancila }}^{\mathbf{I}}$ & fresh water garfish & VU & $\mathrm{LC}$ & $0.22 \pm 0.1$ \\
\hline \multicolumn{5}{|l|}{ Channidae } \\
\hline $6 \quad$ Channa cf. $\operatorname{ara}^{\mathbf{E}}$ & giant snakehead & VU & $\mathrm{LC}$ & $0.20 \pm 0.1$ \\
\hline Channa punctata ${ }^{\mathbf{I}}$ & spotted snakehead & NT & $\mathrm{LC}$ & $0.34 \pm 0.2$ \\
\hline Channa striata $^{\mathbf{I}}$ & murrel & $\mathrm{LC}$ & $\mathrm{LC}$ & $0.23 \pm 0.1$ \\
\hline \multicolumn{5}{|l|}{ Cichlidae } \\
\hline Etroplus suratensis ${ }^{\mathbf{I}}$ & green chromide & $\mathrm{LC}$ & $\mathrm{LC}$ & $0.22 \pm 0.1$ \\
\hline Oreochromis mossambicus * & Mozambique tilapia & - & VU & $0.27 \pm 0.1$ \\
\hline \multicolumn{5}{|l|}{ Clariidae } \\
\hline 11 Clarias brachysoma $^{\mathbf{E}}$ & walking catfish & NT & NT & $0.22 \pm 0.1$ \\
\hline \multicolumn{5}{|l|}{ Cobitidae } \\
\hline 12 Lepidocephalichthys thermalis ${ }^{\mathbf{I}}$ & common spiny loach & $\mathrm{LC}$ & $\mathrm{LC}$ & $0.29 \pm 0.1$ \\
\hline \multicolumn{5}{|l|}{ Cyprinidae } \\
\hline 13 Amblypharyngodon grandisquammis ${ }^{\mathbf{E}}$ & large silver carplet & $\mathrm{LC}$ & $\mathrm{LC}$ & $0.27 \pm 0.1$ \\
\hline Devario malabaricus $\mathbf{I}$ & giant danio & $\mathrm{LC}$ & $\mathrm{LC}$ & $0.24 \pm 0.1$ \\
\hline 15 Dawkinsia filamentosae ${ }^{\mathbf{I}}$ & filamented barb & $\mathrm{LC}$ & $\mathrm{LC}$ & $3.30 \pm 1.1$ \\
\hline Esomus thermoicos $\mathbf{I}$ & flying barb & $\mathrm{LC}$ & $\mathrm{LC}$ & $2.33 \pm 0.7$ \\
\hline Laubuka varuna $^{\mathbf{E}}$ & southern laubuca & EN & $\mathrm{EN}$ & $2.61 \pm 0.7$ \\
\hline Pethia cumingii ${ }^{\mathbf{E}}$ & Cuming's barb & $\mathrm{EN}$ & $\mathrm{EN}$ & $24.05 \pm 6.5$ \\
\hline Pethia nigrofasciata $^{\mathbf{E}}$ & black ruby barb & VU & VU & $0.14 \pm 0.1$ \\
\hline Puntius kamalika $^{\mathbf{E}}$ & Kamalika's barb & $\mathrm{EN}$ & $\mathrm{EN}$ & $0.15 \pm 0.0$ \\
\hline Puntius kelumi $^{\mathbf{E}}$ & Kalum's barb & EN & $\mathrm{EN}$ & $0.18 \pm 0.1$ \\
\hline Puntius vittatus $\mathbf{I}$ & silver barb & $\mathrm{LC}$ & $\mathrm{LC}$ & $49.89 \pm 4.2$ \\
\hline Rasbora dandia $\mathbf{I}$ & striped rasbora & $\mathrm{LC}$ & $\mathrm{LC}$ & $11.33 \pm 2.8$ \\
\hline Rasbora microcephalus ${ }^{\mathbf{I}}$ & common rasbora & $\mathrm{LC}$ & $\mathrm{LC}$ & $0.23 \pm 0.1$ \\
\hline 25 Systomus sarana $^{\mathbf{I}}$ & olive barb & $\mathrm{LC}$ & $\mathrm{LC}$ & $0.30 \pm 0.2$ \\
\hline \multicolumn{5}{|l|}{ Eleotridae } \\
\hline 26 Eleotris fusca ${ }^{\mathbf{I}}$ & brown gudgeon & $\mathrm{LC}$ & $\mathrm{LC}$ & $0.11 \pm 0.1$ \\
\hline \multicolumn{5}{|l|}{ Gobiidae } \\
\hline 27 Awaous melanocephalus I & scribbled goby & $\mathrm{LC}$ & $\mathrm{LC}$ & $0.23 \pm 0.1$ \\
\hline \multicolumn{5}{|l|}{ Heteropneustidae } \\
\hline 28 Heteropneustes fossilis I & stinging catfish & $\mathrm{LC}$ & $\mathrm{LC}$ & $0.25 \pm 0.1$ \\
\hline \multicolumn{5}{|l|}{ Loricariidae } \\
\hline $\begin{array}{l}29 \text { Pterygoplichthys pardalis* } \\
\text { or P.disjunctivus* }\end{array}$ & orinoco sailfin catfish & - & - & $0.12 \pm 0.1$ \\
\hline \multicolumn{5}{|l|}{ Mastacembelidae } \\
\hline $30 \quad$ Mastacembelus armatus I & marbled spiny eel & $\mathrm{LC}$ & $\mathrm{LC}$ & $0.32 \pm 0.1$ \\
\hline \multicolumn{5}{|l|}{ Osphronemidae } \\
\hline 31 Osphronemus goramy* & giant gourami & - & $\mathrm{LC}$ & $0.44 \pm 0.2$ \\
\hline Pseudosphromenus cupanus I & spiketailed paradisefish & $\mathrm{LC}$ & $\mathrm{LC}$ & $0.19 \pm 0.1$ \\
\hline Trichopodus pectoralis* & snakeskin gourami & - & $\mathrm{LC}$ & $0.28 \pm 0.1$ \\
\hline Siluridae & & & & \\
\hline 34 Ompok argestes $^{\mathbf{E}}$ & wet zone butter catfish & VU & VU & $0.29 \pm 0.1$ \\
\hline
\end{tabular}

